\title{
Pengembangan Media Pembelajaran Berbasis Web Pada Mata Kuliah Rekayasa Perangkat Lunak
}

\author{
Joko Kuswanto \\ Program Studi Informatika, Universitas Baturaja, Sumatera Selatam, Indonesia \\ email: jokokuswanto@unbara.ac.id
}

\begin{abstract}
Abstrak
Berbagai macam sumber belajar dan media pembelajaran dibuat, dikembangkan dan digunakan oleh pendidik dalam proses pembelajaran. Media pembelajaran digunakan sebagai perantara dalam rangka memperlancar pencapaian tujuan dari proses pembelajaran, salah satunya adalah media pembelajaran berbasis web. Pemanfaatan web sebagai media pembelajaran masih belum optimal. Penelitian ini bertujuan untuk mengembangkan media pembelajaran berbasis web pada mata kuliah rekayasa perangkat lunak. Jenis penelitian ini merupakan penelitian pengembangan. Tahapan pengembangan media pembelajaran berbasis web menggunakan model ADDIE. Berdasarkan beberapa tahapan pengujian media yang dilakukan kepada para ahli: ahli media $(80,14)$, ahli desain $(80,33)$, dan ahli materi $(80,17)$ dengan kriteria kelayakan Baik. Pengujian kepada peserta didik: skala perorangan $(81,9)$, skala kecil $(81,04)$, dan skala lapangan $(81,7)$ dengan kriteria Baik. Jadi dapat disimpulkan bahwa media pembelajaran berbasis web ini sudah baik dan layak diterapkan dalam pembelajaran mata kuliah rekayasa perangkat lunak.
\end{abstract}

Kata Kunci: pengembangan, web, rekayasa perangkat lunak.

\section{Abstract}

A variety of sources of learning and the media made, developed and used by educators in the process of learning. The media learning used as an intermediary in order to facilitate the achievement of the purpose of the learning process, one of them is the media web-based learning. The use of the web-based learning not optimal. This study aims to to develop media learning web-based on the subjects of engineering software. This research is research development. Stage development web-based learning media use the model ADDIE. Based on several stages of testing media was being done to experts: media experts $(80,14)$, the design $(80,33)$, and the matter $(80,17)$ with criteria feasibility good. Testing to students: one-to-one (81,9), small group (81,04), and field test (81,7) with criteria good. So can conclude that web-based learning media is good and should be applied in learning of engineering software.

Keywords: development, web, engineering software. 


\section{PENDAHULUAN}

Dalam proses pembelajaran dibutuhkan seorang pendidik yang mampu untuk mengintegrasikan seperti teknologi informasi dan komunikasi seiring dengan perkembangan zaman. Sebagai seorang pendidik dituntut untuk dapat secara kreatif mendesain suatu bahan ajar yang memungkinkan peserta didik dapat secara langsung memanfaatkan sumber belajar yang tersedia (Kuswanto, 2019).

Berbagai macam sumber belajar dan media pembelajaran dibuat, dikembangkan dan digunakan oleh pendidik dalam proses pembelajaran. Media pembelajaran digunakan sebagai perantara dalam rangka memperlancar pencapaian tujuan dari pelaksanaan pendidikan. Media pembelajaran harus yang bersifat menyalurkan pesan dan dapat merangsang pikiran, dan kemauan siswa sehingga dapat mendorong terjadinya proses belajar pada dirinya (Asnawir, 2002). Salah satu bentuk media pembelajaran tersebut adalah media pembelajaran berbasis web.

Pembelajaran berbasis web memang menjadi populer saat ini, dimana sebuah aplikasi teknologi web digunakan dalam pembelajaran untuk sebuah proses pendidikan. Pembelajaran berbasis yang populer dengan sebutan Web-Based Education (WBE) atau kadang disebut e-learning (electronic learning) dapat didefinisikan sebagai aplikasi teknologi web dunia pembelajaran untuk sebuah proses pendidikan (Rusman, 2013).

Pembelajaran berbasis web memungkinkan proses pembelajaran dapat dilakukan dimana saja dan kapan saja. Perserta didik dapat belajar sesuai dengan karakteristik dan langkah dirinya sendiri, karena pembelajaran berbasis web membuat pembelajaran bersifat individual.

Namun pemanfaatan dari kemajuan teknologi seperti internet (web) saat ini belum dimanfaatkan secara optimal dalam pembelajaran. Berdasarkan fenomena yang terjadi, proses pembelajaran khususnya pada mata kuliah Rekayasa Perangkat Lunak yang dilakukan melalui pemaparan materi dengan media power point. Penggunaan media lain seperti media berbasis web belum dimanfaakan. Padahal, pendidik dan peserta didik sudah memiliki handphone dengan jaringan internet namun belum dimanfaatkan untuk menunjang proses pembelajaran.

Berdasarkan paparan di atas perlu adanya pengembangan media pembelajaran berbasis web pada mata kuliah Rekayasa Perangkat Lunak di Program Studi Informatika, Universitas Baturaja. Media pembelajaran tersebut dapat dijadikan media belajar bagi peserta didik (mahasiswa) baik dikampus maupun diluar kampus, serta dapat digunakan oleh pendidik sebagai media pembelajaran dalam proses belajar mengajar. Selain itu dengan media ini siswa diarahkan agar lebih memanfaatkan Handphone yang dimiliki tidak hanya untuk berkomunikasi namun juga untuk ranah pendidikan.

\section{Media Pembelajaran Berbasis Web}

Pembelajaran berbasis web secara sederhana dapat dikatakan bahwa semua pembelajaran dilakukan dengan memanfaatkan teknologi internet dan selama proses belajar dirasakan terjadi oleh yang mengikutinya, maka kegiatan itu dapat disebut sebagai pembelajaran berbasis web (Rusman, 2013). Pembelajaran dirancang dengan mengintegrasikan pembelajaran berbasis web dalam program pembelajaran. Selain itu diperlukan sebuah desain instruksional sebagai model belajar layakknya dengan kegiatan belajar di ruang kelas yang melibatkan peserta didik terlibat dalam kegiatan belajar (Kuswanto, 2018).

\section{Website}

Website merupakan kumpulan halaman-halaman yang digunakan untuk menampilkan informasi teks, gambar diam atau gerak, animasi, suara, dan atau gabungan dari semuanya, baik yang bersifat statis maupun dinamis yang membentuk satu rangkaian bangunan yang saling terkait, yang masingmasing dihubungkan dengan jaringan-jaringan halaman (Bekti, 2015). 


\section{METODE PENELITIAN}

Metode yang digunakan dalam penelitian ini adalah penelitian pengembangan. Merupakan penelitian yang berorientasi untuk mengembangkan dan memvalidasi produk-produk yang digunakan dalam pendidikan (Borg \& Gall, 2001). Pengembangan media pembelajaran berbasis web ini menggunakan model ADDIE yang merupakan salah satu model design pembelajaran sistematik (Tegeh \& Kirna, 2013). Pemilihan model ini didasari atas pertimbangan bahwa model ini dikembangkan secara sistematis dan berpijak kepada landasan teoritis desain pembelajaran (Tegeh et al., 2014).

Data evaluasi dalam penelitian ini dibagi menjadi beberapa bagian yaitu (1) evaluasi ahli (ahli desain, media, dan materi) (2) evaluasi skala perorangan, kelompok kecil dan uji lapangan. Untuk menghitung besarnya nilai persentase dari penilaian produk menggunakan persamaam (1) sebagai berikut (Sudijono, 2012):

$$
\mathrm{P}=\frac{f}{N} \times 100 \%
$$

\section{Keterangan:}

$\mathrm{f}=$ Frekuensi yang sedang dicari persentasenya

$\mathrm{N}=$ Number of case (jumlah frekuensi/banyaknya individu)

$\mathrm{P}=$ Angka persentase

\section{HASIL DAN PEMBAHASAN}

\section{Hasil Penelitian}

Model pengembangan yang digunakan dalam pengembangan media pembelajaran berbasis web ini adalah model ADDIE dengan langkah-langkahnya adalah:

1. Analisis (analyze)

Pada tahap ini didapatkan hasil analisis berupa kompetensi dan materi sesuai dengan kurikulum yang berlaku di Prodi Informatika.

2. Perancangan(design)

Pada tahap ini dilakukan perancangan terhadap desain media sesuai dengan karakteristik peserta didik.

3. Pengembangan (development)

Tahap ini yaitu menerjemahkan spesifikasi desain ke dalam bentuk fisik, sehingga dihasilkan prototipe produk pengembangan.

4. Implementasi (implementation)

Hasil pengembangan media diterapkan dalam proses pembelajaran untuk mengetahui pengaruhnya terhadap kualitas pembelajaran.

5. Evaluasi (evaluation)

Evaluasi dilakukan untuk mengumpulkan data pada setiap tahapan yang digunakan untuk penyempurnaan dari media pembelajaran yang dikembangkan

Hasil akhir dari penelitian ini adalah pengembangan media pembelajaran berbasis web yang digunakan sebagai media pembelajaran. Aplikasi yang dikembangkan terdiri atas beberapa halaman yang saling terhubung, berikut tampilan dari halaman media pembelajaran berbasis web: 


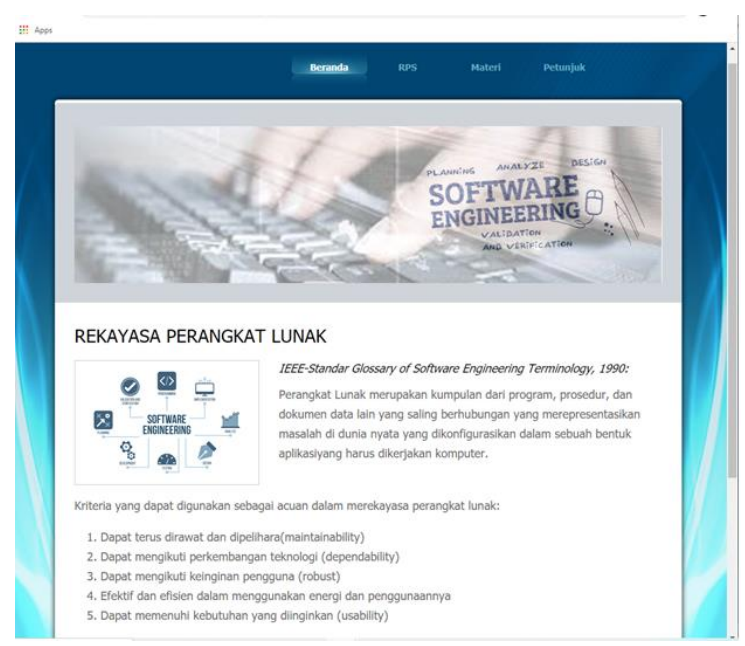

Gambar 1. Tampilan Beranda

Gambar 1 merupakan halaman beranda atau tampilan utama yang berisi beberapa menu seperti: Beranda, RPS, Materi dan Petunjuk.

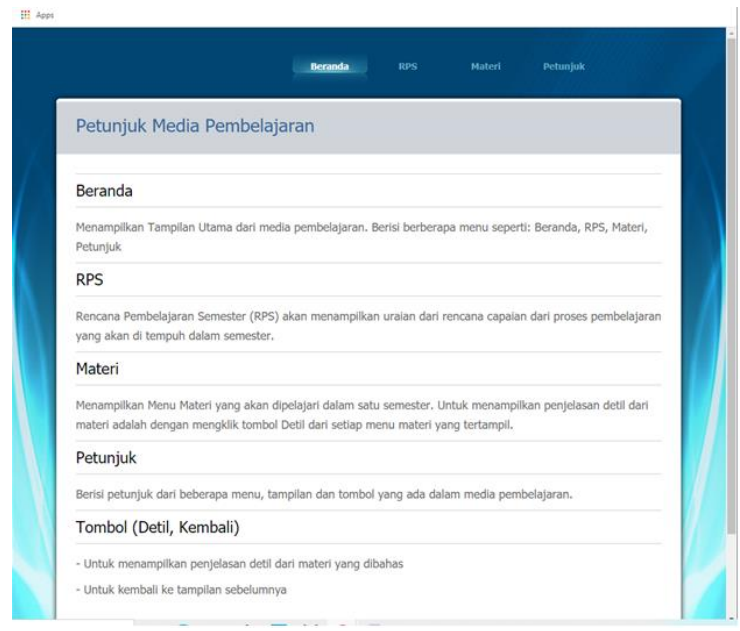

Gambar 2. Tampilan Petunjuk

Gambar 2 Halaman petunjuk yang berisi informasi mengenai petunjuk umum cara pemakaian media pembelajaran yaitu mengenai fungsi-fungsi tombol atau tampilan yang digunakan dalam media.

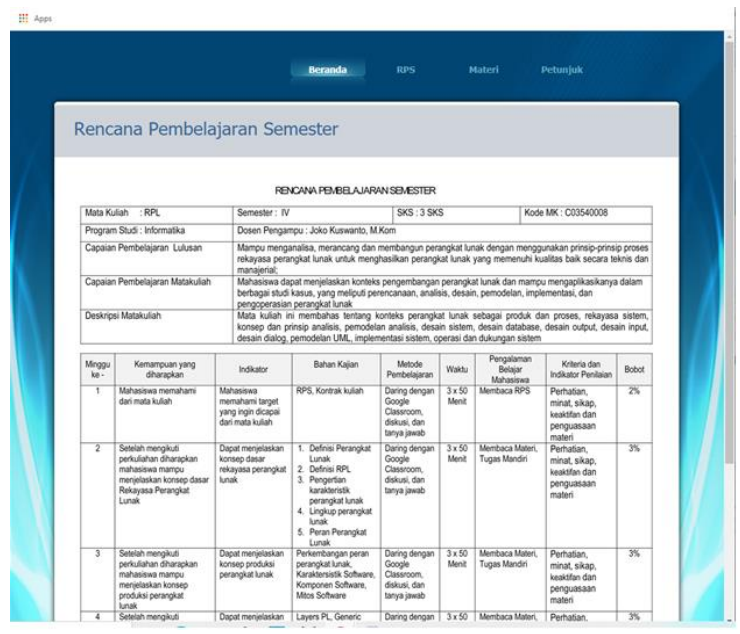

Gambar 3. Tampilan RPS 
Gambar 3 Halaman RPS (Rencana Pembelajaran Semester) yang berisi informasi mengenai rencana, tujuan dan capaian yang akan dijalani dalam satu semester.

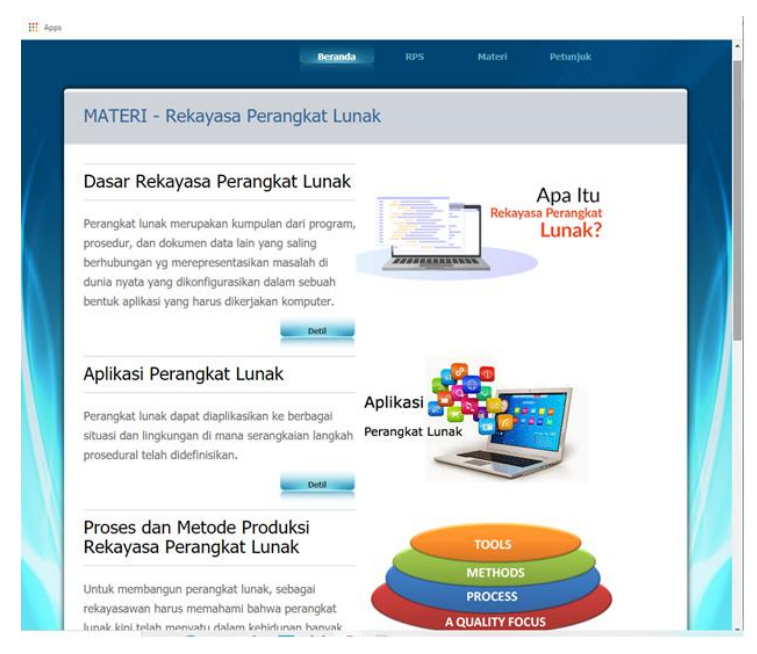

Gambar 4. Tampilan Materi

Gambar 4 tampilan materi. Halaman materi ini menampilkan materi-materi yang akan dipelajari selama satu semester, unuk menampilkan penjelasan materi lebih detil, maka klik tombol Detil. Setelah tombol diklik, maka akan ditampilkan halaman materi secara detil. Gambar 5 menunjukkan tampilan detil materi.

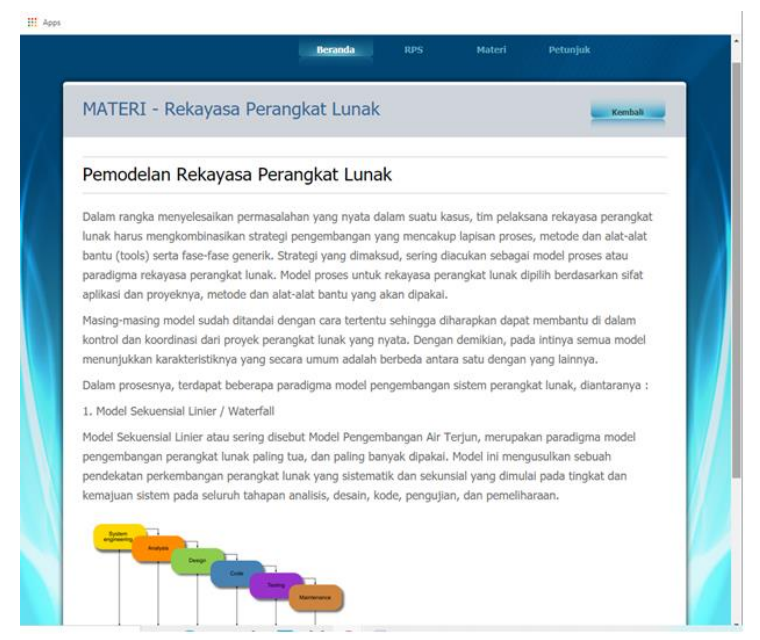

Gambar 5. Tampilan Detil Materi

\section{Pembahasan}

Setelah media pembelajaran dikembangkan sesuai dengan tahapan model ADDIE (analisis, perancangan, pengembangan, implementasi dan evaluasi), maka langkah berikutnya adalah melakukan validasi dan uji coba terhadap produk yang dihasilkan. Tahap awal yaitu evaluasi pramaster yang diawali kepada para ahli (ahli desain, ahli media, dan ahli materi). Untuk hasil evaluasi atau penilaian yang dilakukan kepada para ahli adalah ditunjukkan melalui Tabel 1 sebagai berikut:

Tabel 1. Hasil validasi ahli

\begin{tabular}{llll}
\hline No & Uji Kelayakan & Presentase & Ket \\
\hline 1 & Ahli Materi & $80,17 \%$ & Baik \\
2 & Ahli Desain & $80,33 \%$ & Baik \\
3 & Ahli Media & $80,14 \%$ & Baik \\
\hline
\end{tabular}


Setelah dilakukan evaluasi atau penilaian kepada para ahli, dilanjutkan dengan evaluasi skala perorangan, skala kecil dan skala besar. Skala perorangan dilakukan untuk mengevaluasi media yang dikembangkan diawal dengan jumlah responden sebanyak 3 orang dengan kriteria tinggi, sedang dan rendah.

Selanjutnya dilakukan evaluasi kecil dilakukan dengan jumlah responden sebanyak 8 responden. Terakhir dilakukan evaluasi skala besar atau uji lapangan dengan jumlah responden sebanyak 18 orang responden. Berikut dapat dilihat pada Tabel 2 yaitu hasil evaluasi atau penilaian dari skala perorangan, skala kecil dan skala besar:

\begin{tabular}{llll}
\multicolumn{4}{c}{ Tabel 2. Hasil uji coba } \\
\hline No & Uji Kelayakan & Presentase & Ket \\
\hline 1 & Perorangan & $81,9 \%$ & Baik \\
2 & Skala Kecil & $81,04 \%$ & Baik \\
3 & Skala Besar & $81,7 \%$ & Baik Sekali \\
\hline
\end{tabular}

\section{KESIMPULAN}

Pengembangan media pembelajaran berbasis webdengan model ADDIE dikembangkan melalui beberapa tahap yaitu tahap validasi ahli dan tahap uji coba. Hasil validasiahli yang dilakukan yaituAhli Materi diperoleh 80,17, Ahli Desain diperoleh 80,33, dan Ahli Media 80,14. Hasil validasi untuk ketiga ahli dengan predikat baik.

Untuk uji coba yang dilakukan dalam penelitian ini yaitu untuk uji coba perorangan diperoleh rata-rata persentase 81,9 dengan predikat baik, uji coba skala kecil diperoleh rata-rata persentase 81,04dengan predikat baik, dan uji coba skala besar diperoleh rata-rata persentase 81,7 dengan predikat baik. Jadi secara keseluruhan nilai rata-rata persentase pada responden memperoleh kriteria kelayakan Baik. Berdasarkan hasil penilaian yang dilakukan kepada ahli dan responden dapat disimpulkan bahwa media pembelajaran berbasis web yang dikembangkan sudah layak diterapkan dalam pembelajaran mata kuliah Rekayasa Perangkat Lunak.

Sesuai dengan hasil penelitian yang telah dipaparkan, peneliti memberikan saran pada peneliti berikutnya, yaitu untuk dapat mengembangkan dan membenahi penyusunan program pembelajaran pembelajaran berbasis web dengan menambahkan materi berbentuk video dan menambahkan soal-soal untuk latihan atau evaluasi.

\section{DAFTAR PUSTAKA}

Asnawir, Usman Basyiruddin. (2002). Media Pembelajaran. Ciputat Pers, Jakarta Selatan,

Bekti, Humaira' Bintu. (2015). Mahir Membuat Website dengan Adobe Dreamweaver CS6, CSS dan JQuery. Yogyakarta: ANDI.

Borg, W. R. \& Gall, M. D. (2003). Educational research: an introduction (7th ed.). New York: Longman, Inc.

Kuswanto, Joko. (2018). Media Pembelajaran Berbasis Web Pada Mata Pelajaran Biologi Kelas X. Perspektif Pendidikan, Vol. 12, No. 2.

Kuswanto, Joko. (2019). Pengembangan Modul Interaktif Pada Mata Pelajaran IPA Terpadu Kelas VIII. Media Infotama, Vol. 15, No. 2.

Rusman. (2013). Belajar dan Pembelajaran Berbasis Komputer. Bandung: Alfabeta.

16 | Pengembangan Media Pembelajaran Berbasis Web Pada Mata Kuliah Rekayasa Perangkat Lunak 
Sudijono, Anas. (2012). Pengantar Statistik Pendidikan: Jakarta: PT Raja Grafindo Persada.

Tegeh, I Made \& Kirna, I Made. (2013). Pengembangan Bahan Ajar Metode Penelitian Pendidikan Dengan Addie Model. Jurnal IKA. Vol 13 No 1, Maret 2013, 12-26.

Tegeh, I Made., Jampel. I Nyoman., dan Pudjawan, Ketut. (2014). Model Penelitian Pengembangan. Yogyakarta: Graha Ilmu. 
